\title{
THE LANHAM ACT AND THE SOCIAL FUNCTION OF TRADE-MARKS
}

\author{
EDWARD S. Rogers*
}

Lawyers are so in the habit of thinking of trade-marks in their legal aspects that they sometimes lose sight of the social values that are implicit in them. I am going to take the liberty of recalling a little of the philosophy underlying trademarks as a social institution, and the need of protecting them against misuse.

Trade-marks are one of the oldest of human institutions. Wherever are found the remains of early civilizations, in Egypt, Crete, Greece, or Rome, things with trade-marks on them turn up. Indeed, an industrious antiquarian was able to compile a directory of the lamp makers of ancient Athens from the marks on the broken clay lamps that were found in the city refuse heaps.

The Egyptian law required the owner of every brickyard to place his name on the bricks he sold, and also the name of the slave who actually made the bricks, so that responsibility for defective bricks could be fixed. This practice was a characteristic of the guild system of the Middle Ages. All manufactures- "misteries," as they were called-were confined to trade guilds. No one could engage in trade unless he was a member of such a trade union. The guild statutes required each article made to bear the guild mark, accompanied by the mark of the individual artisan. This was for two purposes. The guild mark was required to show that the article was not contraband - that is to say, non-union-and the requirement that the individual artisan's mark be stamped on the goods was to fix responsibility for bad work, so that the slovenly worker could be identified and disciplined. For example, helmet makers petitioned in 1347 against the foreigners who, not knowing their trade, intermeddled in the making of helmetry, "by reason whereof many great men and others of the realm have been slain through their default." The law of the armorers compelled each member of the guild to mark his product to fix responsibility within the guild for faulty work. And the reason was clear enough. A fighting man staked his life on the wweapons he bore and the armor he wore, and, if anything went wrong, his widow or next of kin wanted to find the varlet who was responsible.

- LL.B. 1895, University of Michigan. Member of Illinois and New York bars. Lecturer on Law of Trade-Marks and Unfair Competition, University of Michigan. Chairman of Board, Sterling Drug Inc., New York. American delegate to Inter-American Conference to Negotiate Convention of Trade-Marks and Commercial Names, r929.

With deep regret, the editors of Law and Contemporary Problems record the fact that Mr. Rogers, loved and respected dean of the trade-mark bar, died shortly before the publication of this symposium. We are honored in the opportunity to bring to his profession this paper, written for this symposium in the closing months of his life-the product of his rich experience and his intimate leadership of the long struggle to revise the statutory law of trade-marks. [Ed.] 
These were in the nature of public regulations. Some artisans being better than others, by a gradual process of evolution certain marks came to connote good workmanship and, hence, to symbolize good will, like a modern trade-mark. With the break-up of the guild system, marks of this kind survived and with them the modern idea of trade-marks symbolizing good will or good reputation and having an asset value.

\section{What Good WiLL Is}

\section{A. The Identification of Persons}

Perhaps a digression into the seemingly irrelevant may help us to an understanding of what good will is, by considering the term as applied to people. Individual good will is nothing but the friendliness that others feel toward a person. Its existence depends on the ability to distinguish one person from another. Try to imagine for a minute what the world would be like if no one could be identified, if everybody looked so much like everybody else that people could not distinguish anybody from everybody. Fancy the state of morals if it were impossible for any individual, by face, figure, or dress, to differentiate himself from others exactly like him. No one could be held responsible for any of his acts. Crime could not be punished because criminals could not be distinguished from honest men. No one could get any credit for good behavior or discredit for bad. Gresham's law would prevail, and everybody would soon be on the level of the worst. I do not think that I would like to live in a world where everyone looked so exactly like everybody else that people could not be told apart-a world where everyone looked, walked, and talked alike, and had no names.

\section{B. How Surnames Happened}

Many centuries ago, surnames were adopted because common names had become too common. They were no longer an identification of a particular person. The common man had only one name. This was the name he was christened withwhat we call his baptismal or Christian name. The result was that there were a lot of Johns, Peters, Thomases, Richards, and Josephs among the men. Most of the women were Marys, Anns, and Janes.

Imagine living in such a community. When you spoke of John, you had to distinguish the John you meant from all the other Johns by some added name. These were called surnames. "Sur" was used in the sense in which we use it now when we speak of a surcharge or overcharge, or of a surtax, an added tax. A surname is a name over or above a man's baptismal name. These surnames were really nicknames. The meaning of the words "nickname" and "surname" is the same. Nick is from the Middle English $e k e-a l s o$. This also-name, or surname, became an ekename, and this was telescoped into nekename, which became nickname.

Surnames or nicknames were usually descriptive of some characteristic of the person to whom they were applied. Some were occupational. John the smith was John Smith, John the carpenter was John Carpenter. John, the man who made 
bows, was John Bowyer; if he used a bow he was John Bowman or John Archer; if he made arrowheads he was John Arrowsmith; if he put feathers on arrows he was John Fletcher; or he was John Cooper, John Shoemaker, John Waterman, John Tinker, or John Taylor, depending on his occupation. If he could read or write he was John Clark. John's identification might be some physical characteristic, such as Black, Brown, White or Red (Reed); or, if he had light hair, he might be called Fairfax or Blount (blond); or he might be John Short or Long, John High or Low, John Longfellow or John Little, or Pettyjohn. If he was a big man, he would be John Stout, or if he was thin, he might be John Rathbone, i.e., Rattlebone. If he was bald, he was John Ballard. Where John lived might be indicated by the name applied to him. John Street, John Lane and John Alley were examples of this. John who lived by the well was John Wells or John Atwell or Atwater. If he lived on the outskirts of the town, he was called John Townsend to distinguish him from the John who lived in the town, who might be called John Town or perhaps Middleton. John Ford, John Hill, and John Dale are sufficiently obvious.

Language made a difference. Henry's son might be Harrison or Fitz(fils)Henry or McHenry. If he was a foreigner, this fact was indicated by a surname-French, Fleming, or Cornwallis (from Cornwall). Portugal became Portingal and then Pattengill. John might be identified as the son of his father-John Johnson, or, if the father was called Jack, the son would be John Jackson-or Jameson, or Richardson, Rixon, Dixon, or Thomson, as the case might be. Williamson was sometimes shortened to Williams or Wilson. Little Will became Wilkins and his son Wilkinson. Walter was usually shortened to Wat, from which come Watson and Watkins. Brothers did not usually have the same surnames. One might be John Wilson and another Tom Williamson, and their sons might be Williams or Wilkins. Unless a person was very important, it is impossible to trace a genealogy by name alone, and one is justified in raising an incredulous eyebrow at assertions of ancient lineage based on such a premise.

But what I am getting at is that it was socially necessary, almost as soon as community life began, to identify individuals and distinguish them from each other. Identification insured responsibility for conduct. Without identification, there could be no responsibility; the law could not be executed; trading was not possible.

\section{The Need for Indicating the Origin of Goods}

The social need of identifying people is the same as the need of identifying the things they buy. If we suppose that no merchandise could be distinguished from any other-that it were forbidden to mark any goods or put any name, label, or other identification on them-a consumer would fare badly in such a world. A producer would too. There could be no pride of workmanship, no credit for good quality, no responsibility for bad. There would be competition, to be sure, but it would be competition to see who could make the worst goods, not the best; and he would win whose product was the cheapest, poorest, and most dishonest. It could 
not be otherwise. If there were no way to tell the good from the bad, why bother to sell anything but the bad-and the worse, the better? The present-day competitive desire to do better would simply be reversed, and everyone would devote his merchandising and manufacturing energies to the promotion of the worst possible type of goods. Minimum government standards might be set up, but there would be no incentive to better them.

The ability to distinguish between people and the use of distinguishing trademarks and other identifying means on goods prevent this sort of barbarism. Trademarks make identification possible and enable people to buy with the assurance that they are getting the merchandise which by faith or experience they believe to be good, and by the same means to avoid what they dislike or know nothing of. Thus, both good will and ill will, or indifference, can be made effective.

\section{What Good Will Is}

We are apt to think that a trade-mark is one thing, and is more or less a legal abstraction, and that good will is something else equally abstract. Trade-marks, names and brands are merely visible good will, and good will is good reputation as ill will is bad reputation. There have been innumerable definitions of good will. It is hard to improve on Mr. Justice Holmes' statement that good will is the inclination to go back to where you have been well treated. As applied to goods, good will is the tendency to buy again an article which in the past has given satisfaction. But it depends on the ability to discriminate and identify.

Good will is trade expectancy. It is what makes tomorrow's business more than an accident.

\section{E. Jefferson's Views'about Trade-Marks-"They Contribute to Fidelity"}

In I79x there was referred to Thomas Jefferson, then Secretary of State, a petition of Samuel Breck and others, sail-makers of Boston. They prayed "that they may have the exclusive privilege of using particular marks for designating the sail cloth of their manufactory." Mr. Jefferson reported "that it would, in his opinion, contribute to fidelity in the execution of manufacturers, to secure to every manufactory, an exclusive right to some mark on its wares, proper to itself."1

'Trade-marks symbolize reputation, good or bad, and the trade-mark is valuable in exact proportion to the goodness or badness of the reputation which it symbolizes. In this way, as Mr. Jefferson said, trade-marks contribute to fidelity. Thus, I suggest that the encouragement of signs of identity, whatever form they may take, stimulates competition by making possible free choice between competing merchants.

\section{F. Trade-Marks Are the Opposite of Monopoly}

Identification of businesses and goods is the essence of free competition and the opposite of monopoly. There is no point in indicating the maker of goods if there is only one. You buy from him or you don't buy, no matter how bad the service may be. There is nowhere else to go. You must go there or go without. It is only

13 Writings of Thomas JefFerson 157 (A. E. Bergh ed. 1907). 
when two or more are bidding for public favor that there is need for distinguishing. You cannot choose between things unless there are at least two and you can tell them apart. The trade-mark enables you to tell them apart-it is a mark which in trade enables buyers to distinguish competing goods from each other and makes possible the democratic right of free choice.

Historically, it was socially necessary to indicate who made goods so that responsibility for their quality could be fixed, or to tell who owned them so they could be recovered in case of theft or shipwreck; and, as few people were literate, marks were the means of identification used.

Marks which, by association, connoted quality were an asset, but trade-marks are also a liability because the user of them stakes his reputation for better or for worse on his goods; for, good or bad, they can be identified as coming from him. He gets the credit if they are good and the discredit if they are bad. Thus trade-marks soon became what they now are, symbols of responsibility.

Trade-marks, it seems to me, serve a useful social purpose. They have done so for centuries.

\section{The Lanham Act and Its Origins}

At a meeting of the Patent Section of the American Bar Association held in St. Louis in I920, a committee was appointed to investigate the desirability of a revision of the federal trade-mark statutes. A draft of a bill was reported by this committee to the Association at the I92I meeting. This draft was very fully discussed by a large number of lawyers, and many suggestions were made. The committee was continued and, at a meeting of the American Bar Association in San Francisco, in 1922, reported a draft of a bill which was discussed and approved by the Section of Patent, Trade-Mark and Copyright Law and was thereafter approved by the American Bar Association. The committee of the Patent Section consisted of James A. Carr, St. Louis; Melville Church, Washington; James T. Newton, Washington, formerly Commissioner of Patents; Harry D. Nims, New York; A. C. Paul, Minneapolis; William Symons, Washington; and Edward S. Rogers, Chicago. At the instance of this committee, various patent law associations appointed committees to consider the proposed bill, among them The New York Patent Law Association, The American Patent Law Association, The Chicago Patent Law Association, The Philadelphia Patent Law Association, The Pittsburgh Patent Law Association, The Cleveland Patent Law Association, The Association of the Bar of the City of New York, The Merchants Club of New York, and a large number of other organizations interested in the subject, including a committee selected by Mr. Thomas E. Robertson, then Commissioner of Patents, who actively participated in the discussions.

This draft became the so-called Vestal Bill. ${ }^{2}$

The Patent Section of the American Bar Association continued its committee, who pursued their study of the subject in the hope that some day their work might

${ }^{2}$ H. R. 7118, 72nd Cong., tst Sess. (1931). For a more detailed history, see Daphne Robert, The New Trade-Mark Manuai, c. 12, 228 (1947). 
be useful in framing legislation. Naturally, the membership of the committee was changed from time to time.

During the I930's there was an effort in several states to enact new state trademark statutes. It may be said, in passing, that there have been state trade-mark statutes in force for many years. They have been framed along the same general lines, the purpose being to supplement the common law by making infringement of marks registered in the office of the Secretary of State a misdemeanor and generally to secure to the owners of common-law trade-marks additional remedies against infringement, although not requiring state registration as a condition to ownership.

In I934, a concerted attempt was made to secure the enactment of new trademark statutes in the various states. The motive power behind this movement was supplied by so-called trade-mark protective bureaus, which charged fees for effecting state registration. Some of the proposals were passed and were vetoed by the governors; others were defeated in the legislatures. A common feature of these acts was to require registration in the various states as a condition of trade-mark ownership and to provide that marks, however long they might have been used, if not registered within six months of the effective date of the statute, became common property subject to appropriation and registration by anyone; and, as registration created ownership, the registrant, whether the real owner of the mark or not, was thus able to secure to himself property belonging to someone else. The compulsory-registration feature applied to all marks used in a state, whatever the origin of the goods bearing the mark might be. If they were shipped from other states, local registration was compulsory as a prerequisite to the local protection-and indeed the ownership-of the trade-mark.

It is unnecessary to point out the burden that this condition of things would impose upon interstate commerce and the tribute that industry would have to pay. The fees proposed for local registration were substantial; in the case of a non-resident concern owning, as many do, a large number of trade-marks, the tax in the aggregate would be intolerably burdensome. This situation revived among the various bar associations and the owners of trade-marks a renewed interest in the revision of the federal trade-mark law, because it was seen that unless there was a strong federal act, protecting marks used in interstate commerce, the states would step in and there might be forty-eight different state laws which would have to be complied with if trade-mark rights were to be secured. This matter came to a head at the American Bar Association meeting in Los Angeles in 1935. The Trade Mark Committee of the Patent Section was directed to offer suggestions for amending the federal trade-mark law to meet the threatened piecemeal regulation by the various states. Certain suggestions of amendments to existing law were made and approved. The committee was continued. In 1936, at the Boston meeting, additional suggestions for amendment of the existing federal statutes were approved, and the committee was directed to make an investigation and report on two questions: 
I. Is a Federal statute providing in effect for registration of trade-marks used in interstate commerce, which confers substantive trade-mark rights, constitutional?

2. If so, is such a statute desirable?

The committee pursued its investigation and reported to the meeting at Kansas City in 1937, answering both questions in the affirmative and submitting certain draft sections to carry out their recommendations.

When the committee was considering the so-called Vestal Bill, it was satisfied that the whole question of the federal statutory protection of trade-marks could best be dealt with as a whole. The various acts affecting trade-marks were scattered, and when put together were not consistent. So an attempt was made to draft an entirely new statute. Later, the committee seemed to feel that there was much that was good in the Act of $1905,{ }^{3}$ that some amendments might remedy its manifest deficiencies, and that perhaps so ambitious a proposal as the Vestal Bill was unwise. After much consideration the committee got back to its original point of view. Amendments are confusing and an amended statute is usually so much involved as to be impractical. So a draft was made which reverted to the original idea of restatement, to attain simplification and consistency.

The theory of the Vestal Bill was that a federal trade-mark statute is procedural only, a kind of practice act assisting common-law protection by simplifying procedure. The theory of the committee draft was broader. It proceeded on the assumption that under the power to regulate commerce Congress can prohibit the counterfeiting and imitation of trade-marks in commerce over which Congress has control, and that in the interests of industry it should exercise this power. If the mislabeling of food and drugs can be prevented under the Food and Drugs Act, if unfair methods of competition can be suppressed under the Federal Trade Commission Act, under the Robinson-Patman Act, and indeed under the Sherman Antitrust Act, there seemed no reason why Congress should not exercise a like power over markings in general.

Moreover, there are a number of international conventions to which this country is signatory which required or were supposed to require legislation to make them effective. This country had failed to carry out its obligations in this respect.

The draft which was the basis of the Lanham Act embodied four general ideas:

I. To give substantive rights in trade-marks to the owners of them on the theory that a trade-mark is an instrumentality of commerce and is within the plenary power of Congress to regulate interstate and foreign commerce.

2. To preserve the particulars in which experience with the then existing acts had proved valuable.

3. To incorporate those provisions in the Vestal Bill which seemed desirable and which had substantially unanimous professional endorsement.

4. To carry out the obligations which this country has assumed under international conventions.

${ }^{3} 52$ STAT. 638 (1905), as amended, 15 U.S.C. \$8I et seq. (1946). 
The prospect of getting anything through Congress in 1937 was not encouraging. Our committee kept notes and I had a scrapbook in which I stuck ideas that came in from all sorts of places. More as a matter of convenience than anything else, I cast those notes and ideas in the form of a draft statute.

In the winter of 1937 the Commissioner of Patents asked me to come to Washington to see him. He said he had had a conference with Fritz Lanham, who was chairman of the subcommittee of the House Patent Committee dealing with trademarks, and asked me to see Mr. Lanham, which I did. Mr. Lanham said that a large number of piecemeal amendments to the I905 Act had been proposed and that he had been studying the Act and couldn't make head or tail of it; that if it were amended piecemeal it would make incomprehensible what had hitherto been merely obscure. So he asked if anywhere around there was a skeleton draft of a new act that could be used as a sort of clotheshorse to hang things on. I told him I had such a draft and he asked me to leave it with him, which I, of course, was glad to do.

I supposed that Mr. Lanham was just going to study this memorandum and skeleton-it was hardly more than that-and begin to hold hearings. I was surprised when, on January 19, 1938, he introduced it as H.R. 904I.

Immediately bar associations appointed committees which did thoughtful and conscientious work, with the result that we now have a new Trade-Mark Act. Since the last Act was passed in 1905 and the new Act in 1946-forty-one years later-I suspect we are going to have to live with the Lanham Act for a long time.

But there is one thing I think we ought to bear in mind: that the people who are responsible for the Lanham Act are the bar association committees and business generally. The whole idea of free enterprise, as we understand it in this country, is based on the importance of identity and personal responsibility of the producer for the goods he sells, which are evidenced by his trade-marks, names, and brands. If that is the sort of an economy we are to have in this country-and I sincerely hope it is, because we have had it for a good many years and it has worked-then trade-marks and brands should be protected so that an incentive will be given to all manufacturers to produce the best goods they know how and take pride in them -and not merely comply with minimum government specifications. You can't have competition unless you can distinguish the competing goods and choose between them. Trade-marks make this distinction and this choice possible. Without them there could be none.

And, finally, I should like to pay a tribute to Fritz Lanham. No man ever worked harder or more conscientiously. Without him there would be no Lanham Act. I am glad it is called the Lanham Act, and I hope it always will be.

Senator Pepper, who was chairman of the Senate subcommittee, reported the bill favorably on May 14, I946. Among other things, he said:

75th Cong., 3d Sess. (1938).

560 STAT. 427, 15 U.S.C. \$1051 et seq. (1946). 
Basic Purpose of Trade-Mark Legislation

The purpose underlying any trade-mark statute is twofold. One is to protect the public so it may be confident that, in purchasing a product bearing a particular trademark which it favorably knows, it will get the product which it asks for and wants to get. Secondly, where the owner of a trade-mark has spent energy, time, and money in presenting to the public the product, he is protected in his investment from its misappropriation by pirates and cheats. This is the well-established rule of law protecting both the public and the trade-mark owner. It is succinctly stated by Mr. Justice Frankfurter in Mishawaka Rubber and Woolen Company v. S. S. Kresge Company, decided on May 4, r942:

The protection of trade-marks is the law's recognition of the psychological function of symbols.

Your committee believes the proposed bill accomplishes these two broad basic principles.

\section{Trade-Marks Defeat Monopoly by Stimulating Competition}

This bill, as any other proper legislation on trade-marks, has as its object the protection of trade-marks, securing to the owner the good will of his business and protecting the public against spurious and falsely marked goods. The matter has been approached with the view of protecting trade-marks and making infringement and piracy unprofitable. This can be done without any misgivings and without the fear of fostering hateful monopolies, for no monopoly is involved in trade-mark protection.

Trade-marks are not monopolistic grants like patents and copyrights (Trade-mark Cases, roo U. S. 82). In Prestonettes v. Coty (264 U. S. 359), Mr. Justice Holmes said (368):

It [a trade-mark] does not confer a right to prohibit the use of the word or words. It is not a copyright. *** A trade-mark only gives the right to prohibit the use of it so far as to protect the owner's good will against the sale of another's product as his.

In United Drug Co. v. Rectanus ( 284 U. S. 90, 97-98), Mr. Justice Pitney said:

The owner of a trade-mark may not, like the proprietor of a patented invention make a negative and merely prohibitive use of it as a monopoly.

* In truth, a trade-mark confers no monopoly whatever in a proper sense ***.

There is no essential difference between trade-mark infringement and what is loosely called unfair competition. Unfair competition is the genus of which trade-mark infringement is one of the species; "the law of trade-marks is but a part of the broader law of unfair competition" (United Drug Co. v Rectanus, 248 U. S. 90, 97). All trade-mark cases are cases of unfair competition and involve the same legal wrong. As Mr. Justice Pitney observed in Hanover Star Milling Co. v. Metcalf (240 U. S. 403, $\left.4^{12}\right)$ :

The essence of the wrong consists in the sale of the goods of one manufacturer or vendor for those of another.*

This essential element is the same in trade-mark cases as in cases of unfair competition unaccompanied with trade-mark infringement.

The protection accorded trade-marks is merely protection against swindling.

As Mr. Justice Holmes observed in Dupont v. Masland (244 U. S. I0o, I02): 
The word "property" as applied to trade-marks *** is an unanalyzed expression of certain secondary consequences of the primary fact that the law makes some rudimentary requirements of good faith.

Trade-marks, indeed, are the essence of competition, because they make possible a choice between competing articles by enabling the buyer to distinguish one from the other. Trade-marks encourage the maintenance of quality by securing to the producer the benefit of the good reputation which excellence creates. To protect trademarks, therefore, is to protect the public from deceit, to foster fair competition, and to secure to the business community the advantages of reputation and good will by preventing their diversion from those who have created them to those who have not. This is the end to which this bill is directed.

\section{Purposes of the Present Bill}

There are many reasons why there should be a new trade-mark statute. The present act is substantially the act of February 20, 1905. It has been amended from time to time and supplemented by the act of March 19, r920, which has also been amended in several particulars. The result is a confused situation.

There are many statutes dealing with trade-marks which are widely scattered and difficult of access. There are provisions dealing with trade-marks in tariff acts and other unlikely places. It seems desirable to collect these various statutes and have them in a single enactment.

Moreover, ideas concerning trade-mark protection have changed in the last 40 years and the statutes have not kept pace with the commercial development. In addition the United States has become a party to a number of international conventions dealing with trade-marks, commercial names, and the repression of unfair competition. These conventions have been ratified, but it is a question whether they are self-executing, and whether they do not need to be implemented by appropriate legislation.

Industrialists in this country have been seriously handicapped in securing protection in foreign countries due to our failure to carry out, by statute, our international obligations. There has been no serious attempt fully to secure to nationals of countries signatory to the conventions their trade-mark rights in this country and to protect them against the wrongs for which protection has been guaranteed by the conventions. Naturally under such circumstances foreign governments do not always give to citizens of the United States their convention rights. To remedy this discreditable situation is merely an act of international good faith.

This bill attempts to accomplish these various things:

I. To put all existing trade-mark statutes in a síngle piece of legislation.

2. To carry out by statute our international commitments to the end that American traders in foreign countries may secure the protection to their marks to which they are entitled. Although it has solemnly pledged at inter-American conventions to do so, the United States has failed adequately to protect owners of trade-marks in the other American countries doing business with this country. As a result of this inaction, our business organizations have not received reciprocal advantages in the other Americas. The bill remedies this matter, eliminates these sources of friction with our Latin-American friends, and will facilitate mutual trade in this hemisphere. These features make this bill of primary importance now.

3. To modernize the trade-mark statutes so that they will conform to legitimate present-day business practice. 
4. To remedy constructions of the present acts which have in several instances obscured and perverted their original purpose. These constructions have become so ingrained that the only way to change them is by legislation.

5. Generally to simplify trade-mark practice, to secure trade-mark owners in the goodwill which they have built up, and to protect the public from imposition by the use of counterfeit and imitated marks and false trade descriptions.

The theory once prevailed that protection of trade-marks was entirely a State matter and that the right to a mark was a common-law right. This theory was the basis of previous national trade-mark statutes. Many years ago the Supreme Court held and has recently repeated that there is no Federal common law. It is obvious that the States can change the common law with respect to trade-marks and many of them have, with the possible result that there may be as many different varieties of common law as there are States. A man's rights in his trade-mark in one State may differ widely from the rights which he enjoys in another.

However, trade is no longer local, but is national. Marks used in interstate commerce are properly the subject of Federal regulation. It would seem as if national legislation along national lines securing to the owners of trade-marks in interstate commerce definite rights should be enacted and should be enacted now.

There can be no doubt under the recent decisions of the Supreme Court of the constitutionality of a national act giving substantive as distinguished from merely procedural rights in trade-marks in commerce over which Congress has plenary power, and when it is considered that the protection of trade-marks is merely protection to goodwill, to prevent diversion of trade through misrepresentation, and the protection of the public against deception, a sound public policy requires that trade-marks should receive nationally the greatest protection that can be given them.

Mr. Justice Holmes said in Bourjois \& Co. v. Katzel (26o U. S. 689), in speaking of the protection accorded to a trade-mark $(692)$ :

It deals with a delicate matter that may be of great value but that easily is destroyed, and therefore should be protected with corresponding care.

Of a trade-mark, he said:

It stakes the reputation of the plaintiff upon the character of the goods.

Whenever there was a hearing before any committee on the trade-mark bill, sooner or later there appeared zealous men from the Department of Justice who raised all manner of objections. They asserted that trade-marks are monopolistic and any statutory protection of them plays into the hands of big business and should be discouraged. In vain it was pointed out that what is now big business started as little business-that trade-marks are not, like patents and copyrights, a government grant of an exclusive right, that trade-marks are visible reputation and symbols of good will, that trade-marks are the antithesis of monopoly, and that to protect them is to insure the one whose goods or services they distinguish against fraud and misrepresentation.

No progress seemed to be made with the Department's representatives, who were against not only the protection of trade-marks but trade-marks as an institution. The result of this opposition was the insertion of a provision ${ }^{6}$ granting to

'Hearings before the Senate Committee on H.R. 546r, 78th Cong., Ist. Sess. (1943). 
any government agency the right to cancel any registration. Senator O'Mahoney was very much in favor of this or an equivalent, subscribing to the general doctrine that trade-marks are objectionable and monopolistic.

The provision of Section $x_{4}$ that any government agency might apply to cancel any trade-mark finally went to conference, where it was suggested that if any agency were to be given authority it should be the Federal Trade Commission, and that there should be limitations placed on the authority. The senators then agreed to the present provisions of Section 14. Senator O'Mahoney proposed further to amend the bill to provide that when a trade-mark is or has been used in violation of the antitrust laws, the mark should be forfeited. After much discussion, the amendment was drafted to read "when the mark has been or is being used to violate the antitrust laws" certain rights in it are lost. ${ }^{7}$ Making the provision apply to past conduct, however remote, apparently overrules the established law that the defense of unclean hands (and this is such a defense) applies only to the conditions existing when the complaint was filed and not to a different situation and an earlier date. $^{8}$

I suggest that these provisions have no place in a statute designed to protect trade-marks. The general powers of a court of equity are ample to prevent abusc.

A bill was introduced in the Eightieth Congress ${ }^{\theta}$ designed to eliminate the authority of the Federal Trade Commission to cancel registrations and the reference to the antitrust laws. There is general unanimity of opinion that these provisions are unwise, unnecessary, and unworkable. ${ }^{10}$ These provisions are the result of the neurosis of certain senators and of the Department of Justice according to which the antitrust laws take precedence over everything else. I suggest that this attitude springs from a complete ignorance of trade-marks, their history, and their social values. It almost makes one wish for a return to "good King George's glorious days,"

When noble statesmen did not itch

To interfere in matters which

They do not understand.

\footnotetext{
${ }^{7}$ Sec. $33(b)(7), 60$ STAT. 438 , 15 U.S.C. $\$$ III5(b)(7) (1946).

The Coca-Cola Company v. The Koke Company, 254 U. S. I43 (1920).

'S. 1919, 8oth Cong., Ist Sess. (r947).

${ }^{10}$ For a detailed discussion, see Daphne Robert, The New Trade-Mark Manual 294-297 (1947).
} 